\author{
Łukasz Dudziński, M.A. .a); Piotr Konrad Leszczyński, Ph.D.) \\ a) District Headquarters of the State Fire Service in Lublin / Komenda Miejska Państwowej Straży Pożarnej w Lublinie \\ b) Faculty of Medical Sciences and Health Sciences, Siedlce University of Natural Sciences and Humanities \\ Wydział Nauk Medycznych i Nauk o Zdrowiu, Uniwersytet Przyrodniczo-Humanistyczny w Siedlcach \\ Corresponding author / Autor korespondencyjny: lukasz_dudzinski@o2.pl
}

\title{
Analysis of Data on Inhalation Poisoning using the Example of the Łuków County in the years 2015-2017
}

\section{Analiza danych dotyczących zatruć wziewnych na przykładzie powiatu tukowskiego w latach 2015-2017}

\begin{abstract}
Aim: This article presents an original analysis of inhalation poisoning data using the example of the Łuków County in 2015-2017. The data was obtained from cases to which Emergency Medical Services were dispatched. Most of such exposures were accidental or caused by negligence. and could be avoided by applying appropriate prevention and safety rules.

Introduction: Inhalation poisonings represent a small percentage of all poisonings. They are mainly associated with the heating season and carbon monoxide. The number of inhalation poisonings is much smaller than that of food poisonings, alcohol poisonings or drug overdoses but they also constitute a significant health risk for the public.

Methodology: The study was based on an analysis of medical documentation of the emergency medical services station in Łuków.

The research material was composed of the information contained in the dispatch documentation of EMS teams, i.e. ambulance call records and medical rescue records for events related to inhalation poisoning. The selection of events from all those that occurred during the audited period was made on the basis of:

- information provided by the reporting person to the emergency number 999 or 112,

- ICD-10 code in the medical emergency record, i.e. diagnosis of the cause of the illness or event.

The analysed factors included age, sex, place of intoxication, seasonality and circadian variation of poisoning. The analysis also considered environmental conditions and the influence of stimulants.

Results: In the analysed period there were 80 events related to inhalation poisoning. There were 89 people exposed in 80 events $(65 \%-$ men, $35 \%$ - women). Over $90 \%$ were cases of accidental poisoning. $60 \%$ of the events occurred at $7 \mathrm{am}-7 \mathrm{pm}$ and $40 \%$ of the events occurred at $7 \mathrm{pm}-7$ am. Of all exposures, $90 \%$ were single poisonings and the remaining $10 \%$ were multiple. Most poisonings (78\%) occurred at the place of residence. Among all the victims, $56 \%$ were hospitalized in the county hospital in Łuków, 38\% of patients remained at home (including due to death -20\% or lack of symptoms requiring hospital treatment $-18 \%$ ), and almost $6 \%$ required immediate specialist treatment. Most incidents related to inhalation poisoning in the Łuków County occurred in rural areas - 56 out of 80 . Most inhalation poisonings were caused by $\mathrm{CO}$.

Keywords: inhalation poisoning, carbon monoxide, pesticides, respiratory tract, emergency response team

Type of article: case study
\end{abstract}

Received: 18.01.2019; Reviewed: 06.05.2019; Accepted: 30.06.2019;

Authors ORCID IDs: Ł. Dudziński - 0000-0002-8255-7608; P. K. Leszczyński - 0000-0002-3408-3591;

Percentage contribution: Ł. Dudziński - 70\%; P. K. Leszczyński - 30\%;

Please cite as: SFT Vol. 53 Issue 1, 2019, pp. 174-187, https://doi.org/10.12845/sft.51.3.2019.11;

This is an open access article under the CC BY-SA 4.0 license (https://creativecommons.org/licenses/by-sa/4.0/)

\section{ABSTRAKT}

Cel: W poniższym artykule przedstawiono autorską analizę danych dotyczących zatruć wziewnych powiatu Łukowskiego w latach 2015-2017, do których dysponowane były zespoły ratownictwa medycznego.

Wprowadzenie: Zatrucia wziewne stanowią niewielki odsetek wszystkich zatruć. Głównie kojarzy się je z okresem grzewczym i tlenkiem węgla. Ekspozycje te najczęściej są przypadkowe, dochodzi do nich również z zaniedbania. W większości można ich uniknąć, stosując odpowiednią profilaktykę i zasady bezpieczeństwa.

Metodologia: Badanie miało charakter analizy dokumentacji medycznej Stacji Ratownictwa Medycznego w Łukowie. Materiał pracy stanowiły informacje zawarte w dokumentacji wyjazdowej zespołów ratownictwa medycznego tj. kart zlecenia wyjazdu oraz kart medycznych czynności ratunkowych w zdarzeniach związanych z zatruciem wziewnym 
Selekcji zdarzeń spośród wszystkich, które wystapiły w badanym okresie czasu dokonano na podstawie:

- informacji podanej przez osobę zgłaszającą na numer ratunkowy 999 lub 112,

- kodu ICD10 w karcie medycznych czynności ratunkowych tj. rozpoznania przyczyny choroby lub zdarzenia.

Analizie poddano czynniki takie jak: wiek, płeć, miejsce ekspozycji, sezonowość i cykl dobowy zatruć. W analizie uwzględniono też warunki środowiskowe oraz udział używek.

Wyniki: W 80 zdarzeniach ekspozycji poddanych zostało 89 osób: w tym 65\% to mężczyźni, 35\% - kobiety. Ponad 90\% stanowiły zatrucia przypadkowe. $60 \%$ zdarzeń przypada na okres pomiędzy godzinami 7 a 19, a 40\% - między 19 a 7 . Wśród wszystkich ekspozycji $90 \%$ to zatrucia pojedyncze, pozostałe 10\% - mnogie. Zdecydowana większość zatruć (78\%) wydarzyła się w miejscu zamieszkania. Wśród wszystkich poszkodowanych 56\% było hospitalizowanych w łukowskim szpitalu powiatowym, 38\% osób pozostało w domu (w tym zgon 20\% i brak objawów wymagających leczenia szpitalnego 18\%), a prawie $6 \%$ wymagała szybkiego leczenia specjalistycznego. Przeważająca liczba zdarzeń związanych z zatruciami wziewnymi występuje na terenach wiejskich: 56 z 80. Większość zatruć wziewnych powodowana jest przez CO

Słowa kluczowe: zatrucie wziewne, tlenek węgla, pestycydy, drogi oddechowe, zespół ratownictwa medycznego

Typ artykułu: studium przypadku

Przyjęty: 18.01.2019; Zrecenzowany: 06.05.2019; Zatwierdzony: 30.06.2019

Identyfikatory ORCID autorów: Ł. Dudziński - 0000-0002-8255-7608; P. K. Leszczyński - 0000-0002-3408-3591;

Procentowy wkład merytoryczny: Ł. Dudziński - 70\%; P. K. Leszczyński - 30\%;

Proszę cytować: SFT Vol. 53 Issue 1, 2019, pp. 174-187, https://doi.org/10.12845/sft.51.3.2019.11;

Artykuł udostępniany na licencji CC BY-SA 4.0 (https://creativecommons.org/licenses/by-sa/4.0/).

\section{Introduction}

Inhalation poisonings in the adult population, most of which are accidental, represent a significant threat to the health and life of people. Alongside trauma, they are the third major cause of death, frequent medical services intervention and hospitalisation in Poland [1]. Poison can enter the body through the digestive tract, respiratory system and, less frequently, through body cavities (nose, rectum, vagina). It can penetrate through the skin or be administered parenterally, intramuscularly, subcutaneously or intravenously. In the context of toxicology, the most significant pathways are by digestion and inhalation. Absorption by the respiratory tract is highly efficient due to the large surface area of this tract and the permeability of the air-blood barrier. The respiratory pathway plays a significant role in occupational and accidental poisoning [2].

The most common, and also the best-known, medium of exposure is carbon monoxide, an odourless, colourless gas formed as a result of the incomplete combustion of carbon compounds where there is not enough oxygen in the combustion process. When the room ventilation or flue liners are obstructed, during gas or solid-fuel heating, this gas concentrates inside rooms, which leads to dangerous poisoning [3].

However, cases of inhalation poisoning occur throughout the year and many of those are unrelated to the heating season or carbon monoxide. These are poisonings related to agriculture (during crop spraying, work with silage in silos [4]), deliberate spraying of gas or leaks in public places with large numbers of people present (school, workplace, mass event, such as a sporting occasion or concert). These causes are extremely rare in Poland, as well as in other European countries $[5,6,7]$. We should

\section{Wprowadzenie}

Zatrucia wziewne w populacji dorosłych, głównie niezamierzone, stanowią istotny problem zagrażający zdrowiu i życiu. Są wraz z urazami trzecią przyczyną zgonów w Polsce, a także częstych interwencji służb medycznych i hospitalizacji [1].Trucizna może dostać się do organizmu przez układ pokarmowy, oddechowy, rzadziej przez jamy ciała (donosowo, doodbytniczo, dopochwowo). Może wniknąć przez skórę lub też zostać podana pozajelitowo, domięśniowo, podskórnie lub dożylnie. Z punktu widzenia toksykologii największe znaczenie mają drogi pokarmowa oraz wziewna. Wchłanianie przez układ oddechowy przebiega z wysoką wydajnością ze względu na dużą powierzchnię dróg oddechowych oraz przepuszczalność bariery powietrze - krew. Droga wziewna odgrywa znaczącą rolę w zatruciach zawodowych oraz przypadkowych [2].

Najczęstszym - jednocześnie najbardziej znanym - medium ekspozycji jest tlenek węgla: bezwonny, bezbarwny gaz powstający w wyniku niecałkowitego spalania się związków węgla przy niedostatecznym udziale tlenu w procesie spalania. W przypadku niedrożnej wentylacji pomieszczeń lub przewodów kominowych, podczas ogrzewania gazowego lub paliwem stałym gaz ten koncentruje się w pomieszczeniach, wywołując groźne w skutkach zatrucia [3].

Jednak w skali roku obserwuje się występowanie zatruć wziewnych niezwiązanych ani z okresem grzewczym, ani z tlenkiem węgla. Są to zatrucia w obszarze rolnictwa (podczas prowadzenia oprysków, prac przy silosach z kiszonką [4]), celowe rozpylenie gazu lub rozszczelnienie się instalacji w miejscach publicznych, gdzie przebywa duża liczba osób (szkoła, zakład pracy, impreza masowa typu wydarzenie sportowe, koncert). W Polsce wymie- 
also mention designer drugs, which are available in a variety of forms, including inhaled. In the group of intentional self-poisonings caused by designer drugs, most involve teenagers from 13 to 18 years of age, the majority of which are boys $[8,9,10,11]$.

This paper discusses the causes, frequency, location and seasonality of the inhalation poisonings which occurred in the Łuków County, i.e. the operating area of the Emergency Medical Services Station (SRM) in Łuków, over a period of three years. The scale of the problem of inhalation poisoning is demonstrated on the basis of interventions made by emergency medical services (EMS) teams at SRM Łuków in the Lubelskie Province. The research data was obtained from the medical documentation of the dispatch teams of SRM Łuków. The analysis covered selected parameters increasing the risk of poisoning, such as season, time of day, exposure site, age, sex and other factors, e.g. the influence of alcohol and the number of exposures resulting in death.

\section{Material and methods}

The study involved data from three years of activity of SRM in Łuków, which is dispatched to 7-8 thousand interventions every year, which results in a three-year total of approx. 25 thousand calls. SRM Łuków is a unit subject to the County Hospital in Łuków. We obtained the Director's consent to access the documentation. The analysed data (regarding victims, EMS team call signs and composition, and cooperating services) are anonymous.

Dispatches based on data from the SRM Łuków Log, which lists every departure chronologically, were qualified to the study. The Log also features the basic statistical, address and medical data, information on the dispatcher's decision regarding the urgency of departure and information on handling the patient. By analysing the information contained in the Log, we were able to select those interventions which fulfilled the criteria adopted for this paper. We qualified events for analysis on the basis of the following criteria:

1) reason for the call, i.e. data provided to the ECC dispatcher by the caller (e.g. chest pain, lower limb trauma, high body temperature, vomiting). We also searched for a number of expressions potentially characteristic of inhalation poisoning:

- vision disturbances following the use of gas,

- unconscious in the bathroom,

- collapsed in the bathroom,

- smell of gas inside the house, feeling unwell,

- was in a fire, feeling unwell,

- feeling dizzy in the garage,

- headache after working with crop protection products,

- feeling nauseous after painting,

- designer drug poisoning,

- difficult to communicate with, suspected CO poisoning,

- exposure to smoke,

- feeling unwell, being poisoned by an unspecified substance; nione przyczyny występują niezwykle rzadko, z częstotliwością podobną do innych państw w Europie [5, 6, 7]. Należy też wspomnieć o dopalaczach, które występują w różnych formach, również wziewnej. W grupie zatruć celowych spowodowanych dopalaczami dominuje grupa wiekowa nastolatków - od 13 do 18 roku życia, a w niej zdecydowana większość to chłopcy $[8,9,10,11]$.

Artykuł odnosi się do przyczyn, częstotliwości, lokalizacji i sezonowości zatruć wziewnych, które wystąpiły na terenie powiatu łukowskiego, rejonu operacyjnego Stacji Ratownictwa Medycznego w Łukowie, na przestrzenni trzech lat. Ukazano skalę problemu zatruć wziewnych na podstawie interwencji medycznych zespołów ratownictwa medycznego (ZRM) na przykładzie SRM Łuków w województwie lubelskim. Informacje do badania pozyskano z dokumentacji medycznej zespołów wyjazdowych SRM Łuków. Dokonano oceny wybranych parametrów zwiększających ryzyko wystąpienia zatrucia np: pora roku, pora dnia, miejsce ekspozycji, wiek, płeć, inne czynniki - np. wpływ alkoholu oraz liczby ekspozycji zakończonych zgonem.

\section{Materiał i metody}

Do badania włączono trzy lata działalności SRM w Łukowie, która rocznie realizuje 7-8 tys. interwencji, co w ciągu trzech lat daje liczbę ok. 25 tysięcy wezwań. SRM Łuków jest jednostką podlegającą pod Szpital Powiatowy w Łukowie. Uzyskano zgodę Dyrektora na dostęp do dokumentacji. Analizowane dane (poszkodowani, kryptonimy i składy osobowe ZRM oraz służby współpracujące) są anonimowe.

Do badania kwalifikowano zlecenia na podstawie danych zawartych w Dzienniku SRM, w którym każdy wyjazd jest wpisany chronologicznie w kolejności realizacji. Są tam również ujęte najważniejsze dane statystyczne, adresowe i medyczne, decyzja dyspozytora co do pilności wyjazdu i postępowanie z pacjentem. Analiza zawartych tam informacji pozwoliła na selekcję interwencji spełniających kryteria tematu artykułu. Zdarzenia kwalifikujące się do analizy typowano na podstawie poniższych kryteriów:

1) przyczyny wezwania, czyli danych które przekazał dyspozytorowi w CPR wzywający (np. ból w klatce piersiowej, uraz kończyny dolnej, wysoka temperatura, wymioty). Dodatkowo zwracano uwagę na użyte w wezwaniu określenia potencjalne dla zatruć wziewnych:

- zaburzenia widzenia po użyciu gazu,

- nieprzytomny w łazience,

- zasłabł w łazience,

- zapach gazu w domu, złe samopoczucie,

- uczestnik pożaru, złe samopoczucie,

- zawroty głowy w garażu,

- ból głowy po pracy przy środkach ochrony roślin,

- nudności, po malowaniu,

- zatrucie dopalaczami,

- utrudniony kontakt podejrzenie zatrucia CO,

- ekspozycja na dym,

- złe samopoczucie zatrucie nieznaną substancją; 
2) ICD-10 code, i.e. medical diagnosis according to the International Classification of Diseases and Related Health Problems, entered by the EMS team leader. The leader of the basic team $(P)$ is a medical rescuer or emergency medical services nurse, and in the specialised team (S) - an emergency medical services physician.

In analysing medical diagnoses, we took into account the disease codes potentially associated with inhalation poisoning. Example ICD10 codes relevant to this study:

- T29 - (Thermal and chemical) Burns of multiple regions,

- T41 - Poisoning: inhaled anaesthetics,

- T58 - Toxic effect of carbon monoxide,

- T59 - Toxic effect of other gases, fumes and vapours,

- T60 - Toxic effect of pesticides,

- T65 - Toxic effect of other and unspecified substances,

- T67 - Effects of heat and light,

- X00 - Exposure to uncontrolled fire in building or structure,

- X08 - Exposure to other specified smoke, fire and flames,

- X47 - Accidental poisoning by and exposure to other gases and vapours,

- X67 - Intentional self-poisoning by and exposure to other gases and vapours,

- Y26 - Exposure to smoke, fire and flames, undetermined intent,

- R98 - Unattended death,

- W40 - Explosion of other materials.

\section{Results}

The research material was composed of 80 ambulance call records of the EMS from 2015-2017. Table 1 presents the numbers of departures in each year, cases qualified for analysis and people exposed.
2) kodu ICD-10, czyli rozpoznania medycznego wg międzynarodowej klasyfikacji chorób i przyczyn zachorowania, wpisanego przez lidera ZRM. Liderem zespołu podstawowego $(P)$ jest ratownik medyczny lub pielęgniarka systemu ratownictwa, a w zespole specjalistycznym (S) - lekarz systemu.

Analizując rozpoznania medyczne, zwracano uwagę na kody chorób potencjalnie związanych z zatruciem wziewnym. Przykładowe kody ICD10 istotne dla badania:

- T29 - oparzenia termiczne i chemiczne mnogich okolic ciała,

- T41 - zatrucie środkami znieczulającymi wziewnymi,

- T58 - efekt toksyczny tlenku węgla,

- T59 - efekt toksyczny gazów dymów, par,

- T60 - efekt toksyczny pestycydów,

- T65 - efekt toksyczny innych nieokreślonych substancji,

- T67 - skutki działania gorąca,

- X00 - narażenie na niekontrolowany pożar budynku, budowli,

- X08 - narażenie na inny nieokreślony dym, ogień, płomienie,

- X47 - przypadkowe zatrucie przez narażenie na gazy, pary,

- X 67 - zamierzone zatrucie przez narażenie na gazy, pary,

- Y 26 - narażenie na dym, ogień płomienie o nieokreślonym zamiarze,

- R98 - śmierć nieoczekiwana,

- W 40 - wybuch innych materiałów.

\section{Wyniki}

Materiał badawczy stanowiło 80 kart wyjazdowych ZRM z lat 2015-2017. Liczba wyjazdów w każdym roku, przypadków zakwalifikowanych do analizy oraz osób poddanych ekspozycji obrazuje tabela 1.

Table 1. Summary of the number of EMS team departures in the years 2015-2017

Tabela 1. Zestawienie liczby wyjazdów ZRM w latach 2015-2017

\begin{tabular}{|c|c|c|c|}
\hline $\begin{array}{l}\text { Year } \\
\text { Rok }\end{array}$ & $\begin{array}{l}\text { All EMS team departures } \\
\text { Wszystkie wyjazdy ZRM }\end{array}$ & $\begin{array}{c}\text { The number of poisonings } \\
\text { Liczba zatruć }\end{array}$ & $\begin{array}{l}\text { The number of people exposed } \\
\text { Liczba osób narażonych }\end{array}$ \\
\hline 2015 & 5782 & $29(0.5 \%)$ & 32 \\
\hline 2016 & 7830 & 27 (0.34\%) & 30 \\
\hline 2017 & 7890 & $24(0.3 \%)$ & 27 \\
\hline 2017 & 1.3 & 2.3 & 2.3 \\
\hline
\end{tabular}

Source: Own elaboration.

Źródło: Opracowanie własne.

The data presented in table 1 demonstrates that the total number of EMS team departures is increasing every year. The largest number of inhalation poisoning cases were recorded in 2015 (29), the lowest number - in 2017 (24). Eighteen cases were fatal. Six cases are multiple poisonings (usually involving
Z danych zawartych z tabeli 1 wynika, że z każdym kolejnym rokiem wzrasta ogólna liczna wyjazdów ZRM. Najwięcej przypadków zatruć wziewnych odnotowano w roku 2015 (29), najmniej - w 2017 (24). Osiemnaście przypadków zakończyło się zgonem narażonej osoby. Sześć przypadków to zatrucia mnogie 
relatives, when the issue concerned faulty ventilation or a fire at home in a garage or in a utility building). In each of the studied years, cases connected with the subject of this paper constituted no more than $0.5 \%$ of all interventions by SRM Łuków.

\section{Seasonal and monthly variability in the number of poisonings}

In the analysed years the number of interventions connected with inhalation exposure remained at a similar level (26.6 exposures per year on average). Figure 1 shows the number of interventions per month in the analysed three-year period. The month with the highest number of events covered by the analysis was January 2016 - 9 events. There were no interventions covered by this analysis in July and August 2016 and in July and November 2017 (figure 1). (najczęściej osoby spokrewnione, gdy problem dotyczył wadliwej wentylacji lub pożaru w domu, w garażu, w pomieszczeniach gospodarczych). W każdym badanym roku przypadki związane $z$ tematem badań stanowiły nie więcej niż 0,5\% wszystkich interwencji SRM Łuków.

\section{Zmienność liczby zatruć w ujęciu sezonowym i miesięcznym}

W analizowanych latach liczba interwencji związanych z ekspozycją wziewną utrzymywała się na podobnym poziomie (ze średnią 26,6 ekspozycji na rok). Liczba interwencji przypadająca na każdy z miesięcy $w$ analizowanym trzyletnim okresie obrazuje rycina 1. Miesiącem z największą liczbą zdarzeń objętych analizą jest styczeń 2016 r. - 9 zdarzeń. Natomiast lipiec i sierpień 2016 oraz lipiec i listopad 2017 to miesiące bez interwencji objętych analizą (ryc. 1).

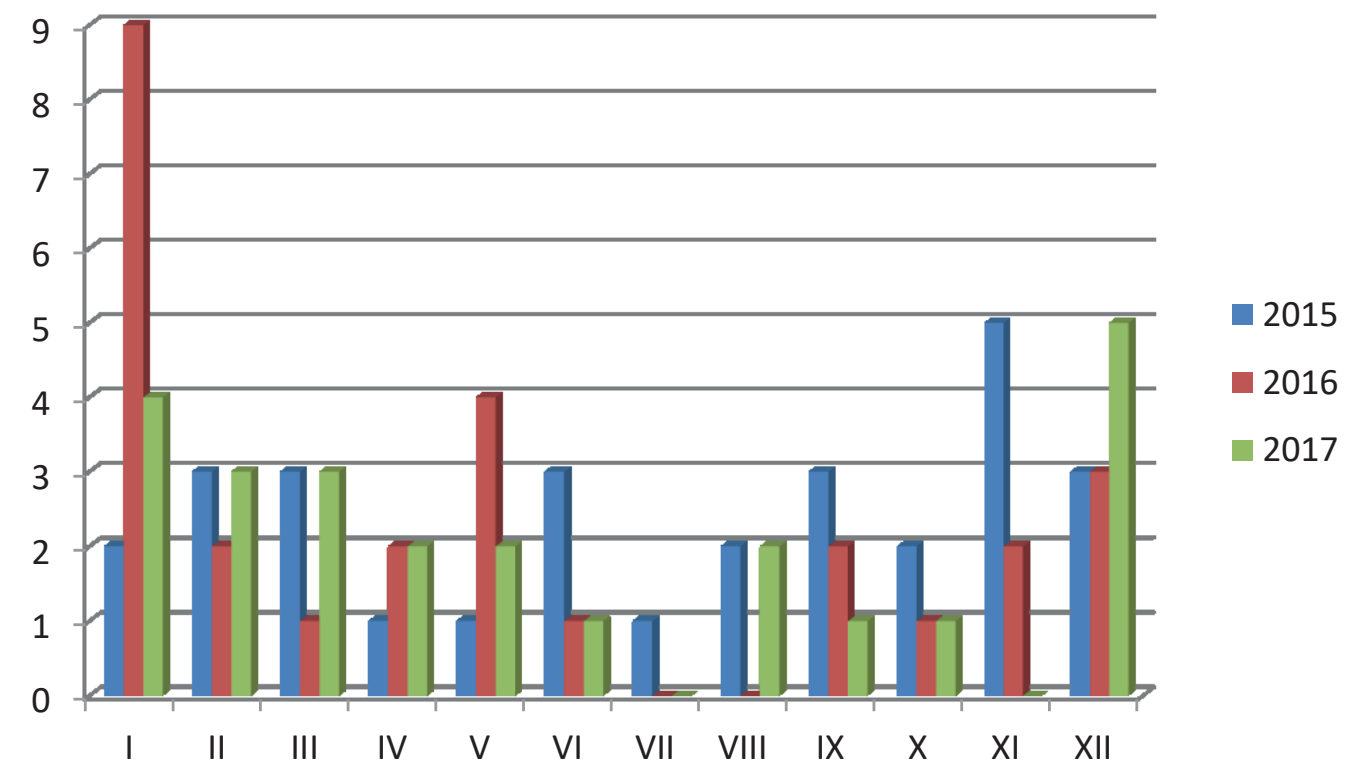

Figure 1. Number of exposures in each month of the three-year analysis period

Rycina 1. Liczba ekspozycji w każdym miesiącu trzyletniego okresu analizy Source: Own elaboration.

Źródło: Opracowanie własne.

\section{Exposure site}

Most events in the analysed period occurred in rural areas (70\%).

Several factors might be involved:

- residents of rural areas are the majority of the county's population (the total population of the county's three towns is less than $\mathbf{4 0}$ thousand, which is illustrated in Figure 2),

- many work establishments (cold store buildings and food processing plants, mushroom farms, welding shops,

\section{Miejsce ekspozycji}

Większość zdarzeń w analizowanym okresie dotyczy terenów wiejskich (70\%).

Może na to wpływać kilka czynników:

- mieszkańcy terenów wiejskich stanowią większość mieszkańców powiatu ( $w$ trzech miastach na terenie powiatu mieszka mniej niż 40 tys. mieszkańców, co graficznie przedstawione jest na rycinie 2),

- wiele zakładów pracy (chłodnie i przetwórnie owoców, pieczarkarnie, zakłady spawalnicze, stacje obsługi po- 
vehicle service centres, craft workshops) are located in rural areas in the outskirts of towns,

- agricultural land and agriculture-related work (crop spraying, work with internal combustion engine equipment),

- residents of towns and cities live in blocks of flats equipped with central heating installations and do not need to use their own boiler rooms. jazdów, zakłady rzemieślnicze) zlokalizowanych jest na terenach wiejskich na obrzeżach miast,

- tereny rolnicze i związane z rolnictwem prace (opryski, prace ze sprzętem spalinowym),

- mieszkańcy miast w blokach posiadają ogrzewanie centralne, nie muszą palić w kotłowniach.

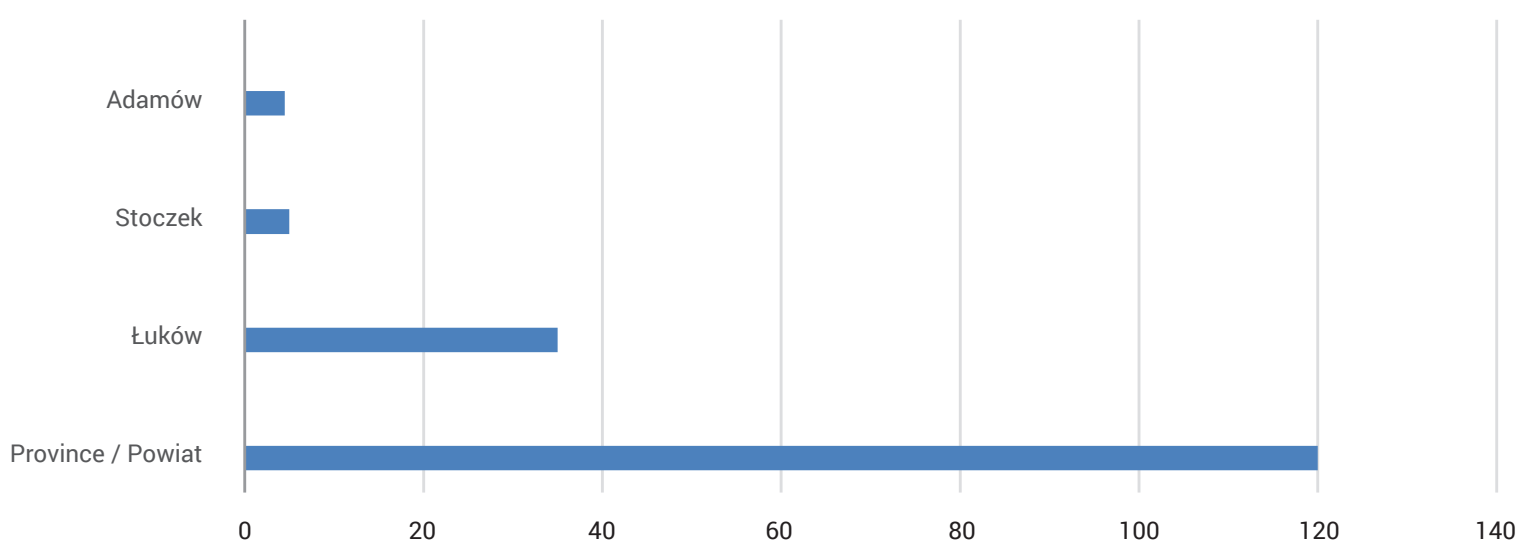

Figure 2. Population of the Łuków County (powiat) and its three towns (in thousands) [12]

Rycina 2. Populacja powiatu łukowskiego i trzech miast (w tysiącach) [12]

The location of the EMS was dictated by the largest population concentrations in the county:

- the town of Łuków - two teams, S and P,

- the town of Stoczek Łukowski - one P team,

- the town of Adamów - one S team.

Figure 3 presents the base locations of dispatch teams of SRM Łuków.

$S$ - specialised team composed of: a physician, a medical rescuer, a medical rescuer-driver, with the physician being the leader of the EMS team.

$P$ - basic team (without a physician) composed of: a medical rescuer / an EMS nurse, a medical rescuer / an EMS nurse, driver. In a $\mathrm{P}$ team one of the medical rescuers or EMS nurses is the leader [14].

The number of departures per EMS team in the analysed material:

- basic team Łuków (P) - 18 events; independent operation, additionally three multiple events (cooperation with Łuków's S team),

- specialised team Łuków (S) - 19 events; independent operation, additionally three multiple events (cooperation with Łuków's $P$ team),

- basic team Stoczek Łukowski - 14 events,

- specialised team Adamów - 26 events.

The health consequences following exposure are affected by the distance from the National Emergency Medical Services station and the units of the National Firefighting and Rescue System, as it translates into the time of starting the intervention and implementing the rescue procedures. In the case of NFRS
Lokalizacja ZRM związana jest z największymi skupiskami ludności w powiecie:

- miasto Łuków - stacjonują dwa zespoły S i P,

- miasto Stoczek Łukowski - stacjonuje jeden zespół P,

- miasto Adamów - stacjonuje jeden zespół S.

Lokalizację zespołów wyjazdowych SRM Łuków obrazuje rycina 3.

$S$ - zespół specjalistyczny w składzie: lekarz, ratownik medyczny, ratownik medyczny - kierowca, w którym lekarz pełni rolę kierownika ZRM

$P$ - zespół podstawowy (tzw. bez lekarza) w składzie: ratownik medyczny / pielęgniarka systemu, ratownik medyczny / pielęgniarka systemu, kierowca. Z zespole $P$ jeden z ratowników medycznych lub pielęgniarek systemu pełni rolę kierownika (lidera) ZRM [14].

Liczba wyjazdów przypadająca na każdy ZRM w analizowanym materiale:

- zespół podstawowy Łuków - osiemnaście zdarzeń; działanie samodzielne, dodatkowo trzy zdarzenia mnogie (współdziałanie z zespołem S z Łukowa),

- zespół specjalistyczny Łuków - dwiewiętnaście zdarzeń; działanie samodzielne, dodatkowo trzy zdarzenia mnogie (współdziałanie z zespołem $\mathrm{P}$ z Łukowa),

- zespół podstawowy Stoczek Łukowski - czternaście zdarzeń,

- zespół specjalistyczny Adamów - dwadzieścia sześć zdarzeń.

Na konsekwencje zdrowotne po wystąpieniu ekspozycji wpływa odległość od miejsca stacjonowania zespołów Państwowego Ratownictwa Medycznego oraz jednostek Krajowego Systemu 
one should take into account the State Fire Service units, as well as some of the Voluntary Fire Service units, which, due to better equipment, training and response time is included in the NFRS.

When the poisoning happened, the victims were at home, work, school or in an agricultural holding (which does not correspond to the statistics for the place of residence). This location was determined by their professional activity, education or everyday matters. Table 2 shows numbers of events by site of exposure.
Ratowniczo Gaśniczego, ponieważ przekłada się ona na czas rozpoczęcia interwencji i wdrożenia procedur ratowniczych. W przypadku KSRG należy brać pod uwagę jednostki PSP i część OSP, która ze względu na lepszy sprzęt, wyszkolenie członków i czas reakcji na wezwanie jest włączona do KSRG. Lokalizacje, w których dochodziło do zatruć - dom, zakład pracy, szkoła, gospodarstwo rolne - to miejsca przebywania poszkodowanych w momencie zdarzenia( nie pokrywające się z statystyką miejsca zamieszkania), wynikające $z$ aktywności zawodowej, edukacji lub spraw codziennych. Dany podział obrazuje tabela 2 z liczbą zdarzeń przypadających dla konkretnego miejsca ekspozycji.

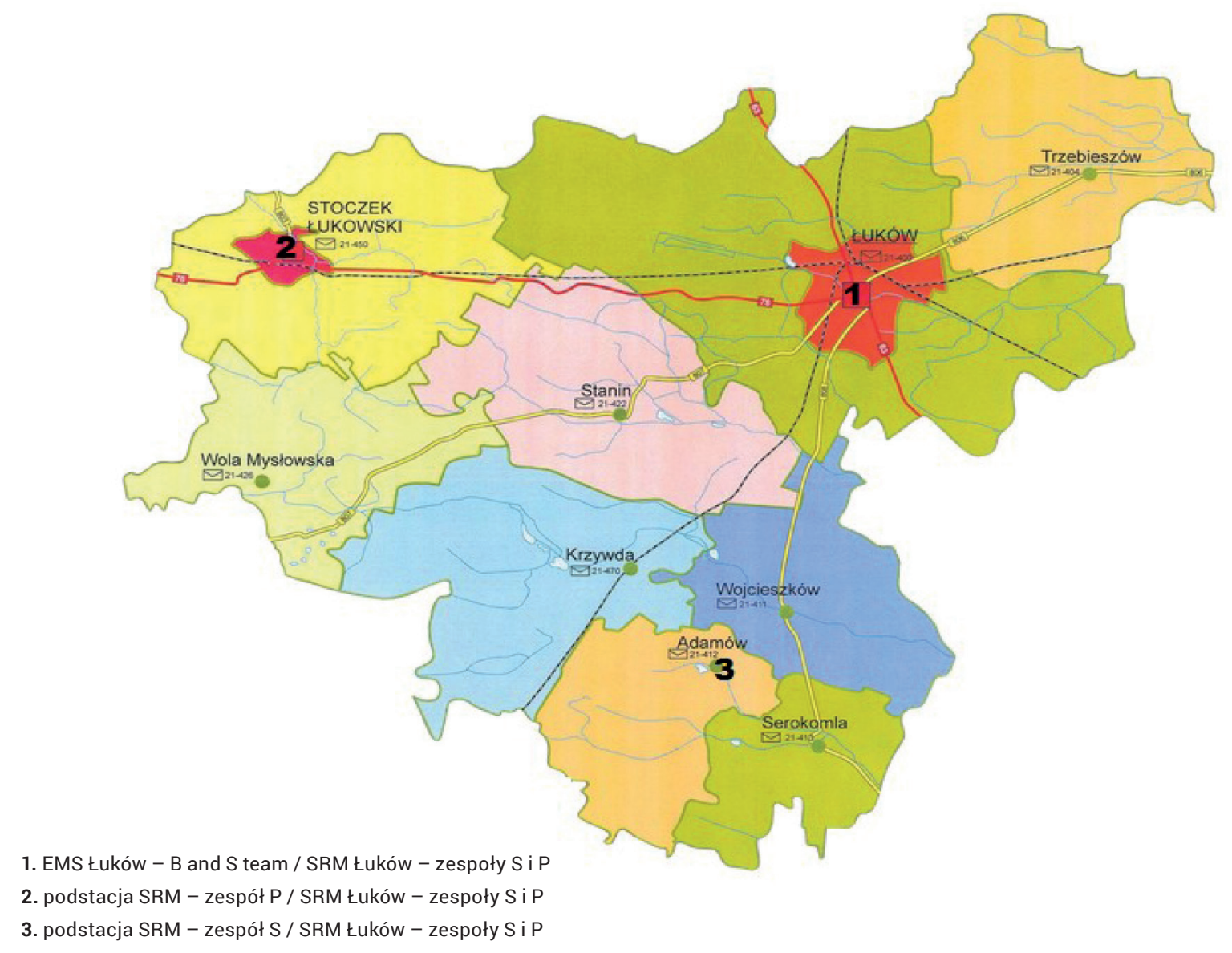

Figure 3. Map of the county with the location of EMS stations [12, 13]

Rycina 3. Mapa powiatu z lokalizacją miejsc stacjonowania ZRM [12, 13]

\section{The age of people exposed to poisoning}

We found that the age groups most exposed to poisoning are $41-50$ and $51-60$. Each of these groups accounts for $22 \%$ of all cases. The everyday responsibilities of people in these age groups cause a greater risk of exposure (heating the house, agricultural work, occupational exposure). The average age of the victims from the analysed interventions was 48.5 years for men and 50.5 years for women. The average age did not take into account two cases with the diagnosis of R96 (found dead on arrival by the EMS) - in both cases it was not possible to deter-

\section{Wiek osób narażonych na zatrucie}

W przeprowadzonej analizie grupa wiekowa najbardziej narażona na zatrucia mieści się w przedziale 41-50 lat oraz 51-60 lat. Oba przedziały wiekowe stanowią po $22 \%$ wszystkich przypadków. Codzienne obowiązki przypisane do tych grup wiekowych powodują większe ryzyko ekspozycji (ogrzewanie domu, prace w rolnictwie, ekspozycje zawodowe). Średnia wieku poszkodowanych z interwencji wziętych do analizy wniosła 48,5 roku dla mężczyzn i 50,5 roku dla kobiet. Do średniej wieku poszkodowanych nie wzięto pod uwagę dwóch przypadków z rozpoznaniem R96 
mine the patient's age. The dispatch team can determine the age on the basis of the patient's documents (identity card, discharge summaries from previous treatment), through interviews with the patient's family or with police assistance. In both discussed cases it was not possible to determine the exact age. The medical emergency records (MER) suggest that the estimated age was around 70 and around 50 years of age. (zgon pacjenta przed przybyciem ZRM) - w obu nie było możliwości ustalenia wieku pacjenta. Zespół wyjazdowy może ustalić wiek na podstawie dokumentów pacjenta (dowód osobisty, karty wypisowe z poprzedniego leczenia), poprzez wywiad z rodziną pacjenta lub przy pomocy policji. W obydwu omawianych przypadkach nie było możliwości ustalenia dokładnego wieku. Z opisu karty medycznych czynności ratunkowych (KMCR) wynika, że mogły to być osoby w szacunkowym wieku ok. 70 i 50 lat.

Table 2. List of events by site of exposure

Tabela 2. Wykaz zdarzeń ze względu na miejsce ekspozycji

No.

Site of exposure / Miejsce ekspozycj

The number of events / Liczba zdarzen

Percentage / Udział [\%]

\begin{tabular}{cccc}
\hline 1 & household & 63 & $78.8 \%$ \\
\hline 2 & agriculture, work in agriculture & 6 & $7.6 \%$ \\
\hline 3 & job, workplace & 3 & $3.7 \%$ \\
\hline 4 & school & 3 & $3.7 \%$ \\
\hline 5 & public place & 3 & $3.7 \%$ \\
\hline 6 & no data & 2 & $2.5 \%$ \\
\hline
\end{tabular}

Source: Own elaboration.

Źródło: Opracowanie własne.

\section{Causes of poisoning}

In the analysis, we tried to determine the causes of poisoning and compared the findings with the later medical diagnosis. The stated reason for the call is often different than actually found and determined by the EMS at the event site. The data provided during the call tend to be inaccurate, incoherent and chaotic, as the calls are often made by random individuals.

The caller acts under the influence of strong emotions, speaking fast or indistinctly. Sometimes the calls are made from sites where there is poor transmission quality. Callers may be under-age or intoxicated by alcohol. On some occasions, it is the victim who calls the EMS, which might present communication difficulties due to the injuries suffered. When calling for help, witnesses and members of the public use colloquial language ("he's lying down", "he fell", "I can't get through to him"). On arrival, the EMS team makes the medical diagnosis, classifying the patient as either unconscious, subject to sudden cardiac arrest or affected by syncope. In every incident, the patient's condition, place of call, number of people involved and reason for the call are verified by the team and the medical diagnosis is determined on the basis of the actual situation, often differing from the information established from the call. Tables 3 and 4 show the differences between the information contained in the EMS call and the medical diagnosis and their percentage share.

The most frequent reason for ambulance calls - unconscious - loss of consciousness - occurred in nine cases (table 3 ). The most common diagnosis - R96 Death - was declared in eighteen of the analysed ambulance calls (table 4).

\section{Przyczyny zatruć}

W analizie podjęto próbę zbadania przyczyn zatruć oraz zestawiono wnioski z późniejszym rozpoznaniem medycznym. Podawana przyczyna wezwania często jest niezgodna z tym, co ZRM zastanie i rozpozna na miejscu zdarzenia. Dane podawane przy wezwaniu mogą być często nieprecyzyjne, niespójne i chaotyczne, ponieważ zgłoszenia dokonuje często osoba przypadkowa.

Wzywający ZRM działa pod wpływem znacznych emocji, mówiąc szybko lub niewyraźnie. Może kontaktować się także z miejsca, które nie gwarantuje dobrej jakości przekazu. Wezwania zespołu może dokonać osoba niepełnoletnia lub osoba pod wpływem alkoholu. Wzywającym może być osoba poszkodowana, z którą kontakt może być utrudniony z powodu doznanych urazów. Świadkowie zdarzenia i osoby postronne wzywające pomoc używają słownictwa potocznego (np. leży, upadł, bez kontaktu). Przybyły na miejsce ZRM ustala rozpoznanie medyczne jako: nieprzytomny, nagłe zatrzymanie krążenia, omdlenie. W każdym incydencie stan pacjenta, miejsce wezwania, liczba osób i przyczyna wezwania jest weryfikowana przez zespół i zgodnie ze stanem faktycznym ustalone zostaje rozpoznanie medyczne sklasyfikowane inaczej niż w wezwaniu. Różnice między informacją zawartą w wezwaniu ZRM a rozpoznaniem medycznym oraz ich udział procentowy w analizie obrazują tabele 3 i 4.

Najczęstsza przyczyna wezwań - nieprzytomny / utrata przytomności - pojawia się w dziewięciu przypadkach (tab. 3). Najczęstsze rozpoznanie - R96 zgon - zapadło przy osiemnastu analizowanych wezwaniach (tab. 4). 
Table 3. The most frequently reported reasons of ambulance calls Tabela 3. Najczęściej zgłaszane przyczyny wezwania

\begin{tabular}{cccc}
\hline \multirow{2}{*}{ No. } & Site of exposure / Miejsce ekspozycji & $\begin{array}{c}\text { The number of events } \\
\text { Liczba zdarzeń }\end{array}$ & Percentage / Udział [\%] \\
\hline 1 & unconscious, loss of consciousness / nieprzytomny, utrata przytomności & 9 & $11.25 \%$ \\
\hline 2 & zawroty głowy / dizziness & 7 & $8.75 \%$ \\
\hline 3 & fainting / zastabnięcie & 5 & $6.25 \%$ \\
\hline 4 & fire / pożar & 5 & $6.25 \%$ \\
\hline 5 & person lying on the ground / leży człowiek & $5 \%$ \\
\hline 6 & nausea / nudności & 5 & $3.75 \%$ \\
\hline 7 & vomiting / wymioty & 4 & $3.75 \%$ \\
\hline 8 & behavioral disorders / zaburzenia zachowania & 3 & $3.75 \%$ \\
\hline 9 & dyspnoea / duszność & 3 & $3.75 \%$ \\
\hline 10 & headache / ból głowy & 3 & $3.75 \%$ \\
\hline 11 & weakness / osłabienie & 3 & $3.75 \%$ \\
\hline 12 & poisoning / zatrucie & 3 & $3.75 \%$ \\
\hline 13 & carbon monoxide / poisoning zatrucie czadem & 3 & $31.25 \%$ \\
\hline
\end{tabular}

Source: Own elaboration.

Źródło: Opracowanie własne.

Table 4. Most frequently entered medical diagnoses for the analysed events

Tabela 4. Najczęściej wpisywane rozpoznania medyczne w analizowanych zdarzeniach

\begin{tabular}{|c|c|c|c|}
\hline No. & Medical diagnoses / rozpoznanie medyczne & Quantity / Liczba & Percentage / Udział [\%] \\
\hline 1 & $\begin{array}{l}\text { R96 - other sudden death, cause unknown } \\
\text { R96 - zgon, przyczyna nieznana }\end{array}$ & 18 & $22.50 \%$ \\
\hline 2 & $\begin{array}{l}\text { R55 - Syncope and collapse } \\
\text { R55 - omdlenie i zapaść }\end{array}$ & 8 & $10 \%$ \\
\hline 3 & $\begin{array}{l}\text { X47 - accidental poisoning by and exposure to other gases and vapours } \\
\text { X47 - przypadkowe zatrucie przez gazy i pary }\end{array}$ & 6 & $7.50 \%$ \\
\hline 4 & $\begin{array}{l}\text { X49 - accidental poisoning by chemicals } \\
\text { X49 - przypadkowe zatrucie przez środki chemiczne }\end{array}$ & 4 & $5 \%$ \\
\hline 5 & $\begin{array}{l}\text { T65 - toxic effect of unspecified substance } \\
\text { T65 - efekt toksyczny nieokreślonych substancji }\end{array}$ & 3 & $3.75 \%$ \\
\hline 6 & $\begin{array}{l}\text { T59 - toxic effect of other gases, fumes and vapours } \\
\text { T59 - efekt toksyczny gazów, dymów, par }\end{array}$ & 3 & $3.75 \%$ \\
\hline 7 & $\begin{array}{l}\text { X69 - intentional self-poisoning by chemicals } \\
\text { X69 - zamierzone zatrucie przez środki chem. }\end{array}$ & 3 & $3.75 \%$ \\
\hline 8 & $\begin{array}{l}\text { other medical diagnoses } \\
\text { inne rozpoznanie medyczne }\end{array}$ & 35 & $43.75 \%$ \\
\hline
\end{tabular}

Source: Own elaboration

Źródło: Opracowanie własne. 
A comparison of data from Table 3 item 1 and Table 4 item 1 highlights a frequent situation occurring when calling EMS. The person calling the ambulance sees a person lying on the ground who is not moving or responding to verbal prompts. As the caller did not witness the person falling and does not know how long the person has been lying, he or she reports that the person is unconscious. In eighteen cases patients were found dead on arrival by the EMS.

\section{The gender of exposed individuals}

Most exposures in the analysed documentation involve men (65\%) and the remaining 35\% are women (this division includes minors). This proportion is caused by several factors. Men are more likely to work in agriculture, in central heating boiler rooms in houses or use internal combustion engines in machines (repair shops, production halls). Alcohol abuse is a factor increasing the risk of fire and inhalation poisoning. The risk level for men and women is similar when the exposure is caused by a random event such as a fire or inadequate ventilation during sleeping hours.

\section{Summary}

Statistical data shows that inhalation poisoning occurs mainly during the winter (heating) season, as most of them are caused by exposure to carbon monoxide and other noxious substances produced in the combustion process. During the winter season there are fires in boiler rooms, soot fires in chimney ducts, leaks in heating systems, smoke rollback events and even cases of deliberate obstruction of ventilation openings (with the intention of keeping the heat inside the house) [15]. The seasonality of carbon monoxide poisonings according to statistics (KG PSP for 2015) is presented in figure 4 . In annual terms, there are between 3,600 and 4,500 such seasonal CO poisonings, which include hospitalisations and deaths (around 8-10\%) [16, 17]. The average monthly numbers of poisonings for the winter months (November - March) are nearly five times higher than for the remaining months (April - October). An analysis for the individual months demonstrates that the presence of poisoning cases depends on outside air temperature - more incidents are recorded when the temperature falls, particularly when average monthly temperatures are below $10^{\circ} \mathrm{C}$.

Figure 4 covers events occurring throughout Poland and Figure 5 presents the local situation (within the county as the area of operation of SRM Łuków). According to our analysis (figure 5), the data regarding the seasonality of inhalation poisonings are quite different from those presented in figure 4.

While inhalation poisoning is commonly associated with the heating season and carbon monoxide, our analysis demonstrated that the distribution of events throughout the year is roughly even in all months. In winter exposures are related to heating and in the summer - with agriculture (crop spraying - crop
Zestawienie danych z tab. 3 poz. 1 i tab. 4 poz. 1 obrazuje częstą sytuację podczas wzywania ZRM. Wzywający widzi osobę, która leży, nie porusza się, nie ma z nią kontaktu słownego. Ponieważ nie był świadkiem tego, jak upadała i nie wie, jak długo leży w zastanym miejscu, traktuje ją jak osobę nieprzytomną i taki stan zgłasza pod numerem alarmowym. Osiemnaście przypadków zakończyło się zgonem osoby poszkodowanej przed przybyciem ZRM.

\section{Płeć narażonych osób}

Większość eskpozycji w analizowanej dokumentacji dotyczy mężczyzn (65\%), pozostałe 35\% ekspozycji odnosi się kobiet (w podziale uwzględniono osoby niepełnoletnie). Na powyższe proporcje wpływa kilka czynników. Mężczyźni częściej prowadzą prace w rolnictwie, w przydomowej kotłowni centralnego ogrzewania pracują z użyciem silników spalinowych w maszynach (warsztaty samochodowe, hale produkcyjne). Nadużywanie alkoholu jest czynnikiem zwiększającym ryzyko pożaru i zatrucia wziewnego. Porównywalne ryzyko ekspozycji zarówno dla mężczyzn, jak i kobiet występuje, gdy przyczyną zdarzenia jest zjawisko losowe: pożar, niewłaściwa wentylacja domu podczas nocnego odpoczynku.

\section{Podsumowanie}

Według danych statystycznych zatrucia wziewne występują głównie w okresie zimowym (grzewczym), ponieważ wśród nich przeważa narażenie na tlenek węgla i substancje szkodliwe występujące podczas procesów spalania. W trakcie sezonu grzewczego dochodzi do pożarów w kotłowniach, pożarów sadzy w układzie kominowym, nieszczelności w układzie grzewczym, cofania się dymu lub wręcz celowego zatykania wentylacji (pozorne utrzymanie ciepła w domu) [15]. Sezonowość zatruć tlenkiem węgla wg statystyk (KG PSP za 2015) pokazuje rycina 4. Rocznie to między 3600 a 4500 przypadków zatruć CO, w tym zawierają się hospitalizacje i zgony (ok. 8-10\%) [16, 17]. Średnie miesięczne liczby zatruć dla miesięcy zimowych (listopad - marzec) blisko pięciokrotnie przewyższają liczbę takich zdarzeń dla pozostałych miesięcy (kwiecień - październik). Analiza dla poszczególnych miesięcy pokazuje zależność występowania zatruć od temperatury powietrza - odnotowanych incydentów jest więcej wraz ze spadkiem temperatury, szczególnie przy średnich temperaturach miesięcznych poniżej $10^{\circ} \mathrm{C}$.

Rycina 4 dotyczy zdarzeń występujących w całym kraju a rycina 5 sytuacji lokalnej (o zasięgu powiatowym jako rejonie działania SRM Łuków). W przeprowadzonej analizie (rycina 5) dane dotyczące sezonowości zatruć wziewnych nieco odbiegają od danych zawartych w rycinie 4 .

Zatrucia wziewne kojarzą się głównie z okresem zimowym i tlenkiem węgla. W prowadzonej analizie rozkład zdarzeń w skali roku utrzymuje się na podobnym poziomie we wszystkich miesiącach. W okresie zimowym są to eskpozycje związane z ogrzewaniem, a w okresie letnim - z rolnictwem (opryski - środki ochrony roślin). Dla zatruć wziewnych celowych, przypadko- 
protection products). For intentional self-poisonings, as well as accidental and occupational poisonings, there is no significant dependence on the season or month. Still, these cases are an important diagnostic and therapeutical issue for $\operatorname{EMS}[18,19]$.

Every year, the National Headquarters of the State Fire Service website publishes statistics of firefighter interventions in a variety of events, including the numbers of injuries and fatalities. In the available data for the 2015/16 and 2016/17 winter seasons the numbers of fatalities caused by carbon monoxide poisoning were 50 and 61 , respectively, and the number of poisoned individuals taken to hospital in both seasons exceeded 2,200 [16]. wych lub związanych z pracą zawodową pora roku i miesiąc nie mają istotnego znaczenia. Stanowią one jednak ważny problem diagnostyczno-terapeutyczny na poziomie ZRM $[18,19]$.

Komenda Główna Państwowej Straży Pożarnej corocznie publikuje na swojej stronie statystyki dotyczące interwencji strażaków w różnych zdarzeniach, uwzględniając $w$ tym również poszkodowanych i ofiar śmiertelnych. W dostępnych danych za sezon zimowy 2015/16 i 2016/17 liczba ofiar śmiertelnych spowodowanych zatruciem tlenu węgla wynosiła odpowiednio 50 i 61 osób, zaś liczba osób poszkodowanych podtrutych przewiezionych do szpitala w obydwu sezonach przekraczała 2200 osób [16].

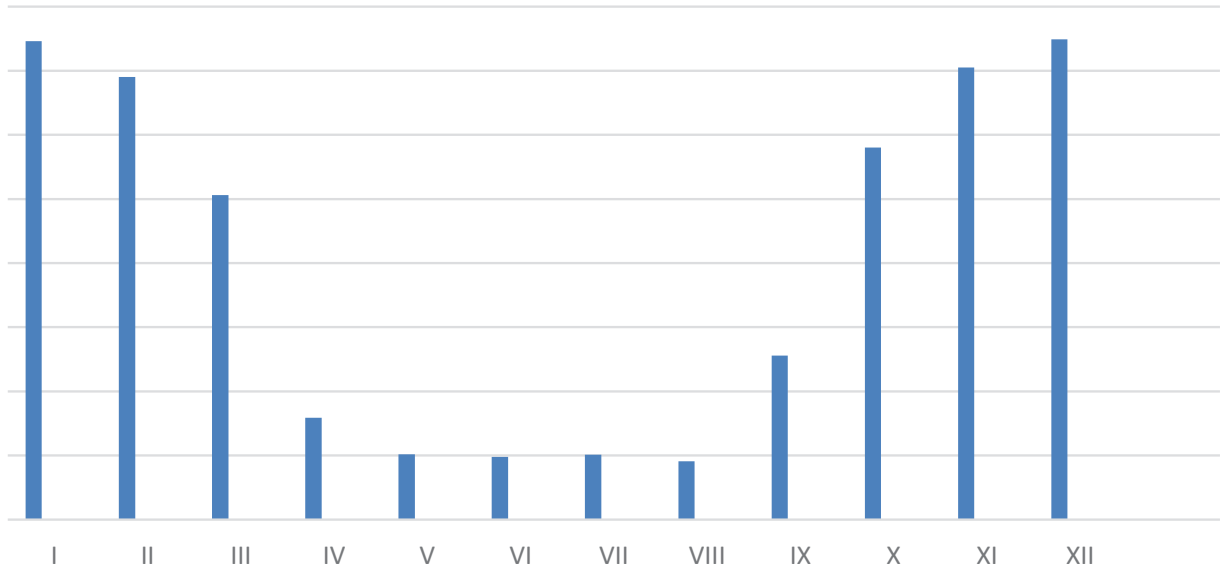

Figure 4. Seasonality of CO poisonings in Poland in 2015 - in months (the National Headquarters of the State Fire Service - KG PSP) [16] Rycina 4. Sezonowość zatruć tlenkiem węgla w Polsce w 2015 r. - w miesiącach (KG PSP) [16]

In our study for the 2015/16 and 2016/17 heating seasons (assuming that the season covers the period from the beginning of September until the end of March), the numbers of victims of events involving carbon monoxide were 25 (including 4 deaths) (2015/16) and 18 (including 3 deaths) (2016/17). The numbers of injuries and deaths in the discussed period are included in the State Fire Service statistics for the whole country. PSP prepares its statistics on the basis of its dispatches and information obtained from EMS and MAR teams, as well as hospitals.

Smoke restricts visibility in a fire, makes breathing difficult, carries toxic compounds and increases egress time. The scale of risk associated with smoke is evidenced in the statistics - burns are responsible only for $25 \%$ of all deaths, as many as $51 \%$ of deaths are caused solely by the toxic combustion and decomposition products, and $23 \%$ of deaths result from exposure to both smoke and fire and secondary trauma. When a fire breaks out in a living space, it consumes numerous items made of plastic, which produce not only carbon monoxide, but also dangerous cyanide compounds. The effect of hydrogen cyanide and its derivatives inhibits cytochrome oxidase, preventing the cells from absorbing oxygen. The data contained in the statistics suggest that if there is a severe fire, then the people present inside are
W badaniach własnych w sezonie grzewczym 2015/16 i 2016/17 (przyjmując za sezon grzewczy okres od początku września do końca marca) liczba osób poszkodowanych w zdarzeniach związanych z tlenkiem węgla wynosiła odpowiednio 2015/16 - 25 osób (w tym 4 osoby zgon), i 2016/17- 18 osób (w tym 3 osoby zgon). Zarówno liczba osób poszkodowanych, jak i ofiar śmiertelnych z omawianego okresu badań własnych wchodzi w skład statystyk PSP dla całego kraju. PSP do w/w statystyk uzyskuje informacje zarówno ze swoich wyjazdów, jak również ZRM i LPR, oraz leczenia szpitalnego.

Dym podczas pożaru zmniejsza widoczność, utrudnia oddychanie, zawiera toksyczne składniki i wydłuża czas ewakuacji. O skali zagrożenia, jakie stanowi, świadczą statystyki: w wyniku poparzeń w pożarach ginie tylko $25 \%$ wszystkich ofiar, aż $51 \%$ zgonów spowodowanych jest działaniem wyłącznie toksycznych produktów spalania i rozkładu, a $23 \%$ osób umiera z powodu działania zarówno dymu, jak i ognia oraz urazów wtórnych. Podczas pożarów w pomieszczeniach mieszkalnych znajduje się dużo przedmiotów z tworzyw sztucznych. Te paląc się, wydzielają nie tylko tlenek węgla, ale równie groźne związki cyjankowe. Działanie kwasu cyjanowodorowego i jego pochodnych hamuje układ enzymatyczny oksydazy cytochromowej, przez co uniemożliwia wykorzystanie tlenu przez komórki. Dane zawarte w statystykach ozna- 
more likely to die from inhalation poisoning than from the direct impact of temperature $[20,21]$.

In addition, carbon monoxide inhalation causes muscle contractions which prevent the still-conscious person from leaving the room [22]. czają że jeśli wystąpi poważny pożar, to znajdujące się w środku osoby najprawdopodobniej zginą poprzez zatrucie wziewne, a nie z powodu bezpośredniego działania temperatury [20, 21].

Dodatkowo pod wpływem tlenku węgla następuje miotonię (skurcz mięśni), która uniemożliwia przytomnej świadomej jeszcze osobie wydostanie się z pomieszczenia [22].

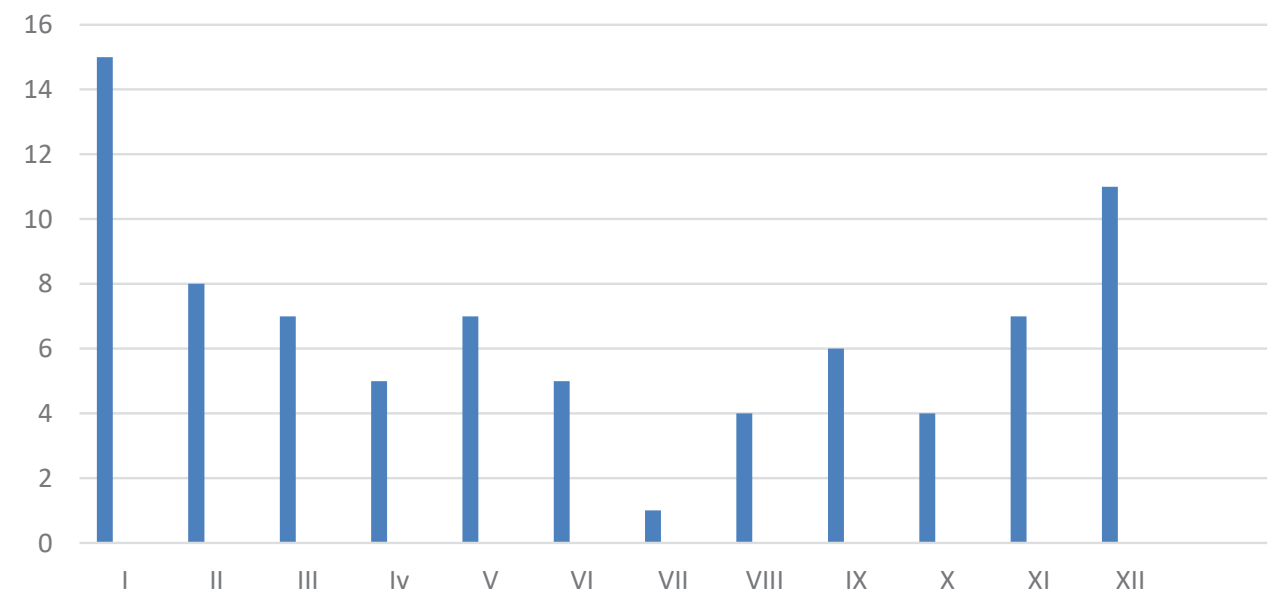

Figure 5. The distribution of events per months in 2015-2017 (from the operating area of the Emergency Medical Services Station in Łuków) Rycina 5. Rozkład zdarzeń z podziałem na miesiące w 2015-2017 (z rejonu operacyjnego Stacji Ratownictwa Medycznego w Łukowie) Source: Own elaboration.

Źródło: Opracowanie własne.

The analysed material contains 12 cases connected with fires in flats, houses or business premises, which occurred when people were inside. Three cases ended in the death of the person being inside and 9 events (involving 11 people) ended in inhalation poisoning or burns. These patients were taken to hospital and most of them were admitted to the nearest ED. Some patients required treatment in a specialised toxicology treatment centre or in a hyperbaric chamber. Oxygen therapy combined with the elevated pressure in the chamber accelerates the process of eliminating carbon monoxide from the body [23, 24].

The studied material contained 18 cases of deaths of victims at the event site (Table 6 ), which constitute $20 \%$ of all victims. The causes of death could not be established at the EMS intervention stage, so it is difficult to confirm the statistics cited in the literature pointing that $51 \%$ of deaths in fires are caused by poisoning due to exposure to toxic combustion products [25]. EMS teams carry out a general examination of the body, which is not sufficient to determine the cause of death [26]. Autopsy reports were not included in the analysed material.

\section{Conclusions}

1. Most incidents related to inhalation poisoning in the Łuków County occur in rural areas.

2. Carbon monoxide is the most common cause of inhalation-related incidents.
W analizowanym materiale wystąpiło 12 przypadków związanych z pożarem mieszkania, domu lub lokalu użytkowego, w którym podczas pożaru znajdowały się osoby. Trzy przypadki zakończyły się zgonem osoby będącej wewnątrz, a 9 zdarzeń (w tym 11 osób) zakończyło się zatruciem wziewnym lub poparzeniem. Osoby te zostały przetransportowane do szpitala, większość na najbliższy SOR. Część osób wymagała leczenia w ośrodku specjalistycznym toksykologicznym bądź w komorze hiperbarycznej. Tlenoterapia przy zwiększonym ciśnieniu panującym w komorze przyspiesza czas eliminacji tlenku węgla z organizmu $[23,24]$.

W badanym materiale wystąpiło 18 przypadków zgonów osób poszkodowanych w miejscu wezwania (tabela. 6), które stanowią $20 \%$ wszystkich poszkodowanych. Przyczyny zgonów nie były możliwe do określenia na etapie ZRM, dlatego trudno potwierdzić dostępne w literaturze statystyki wskazujące 51\% ofiar pożarów umierających wskutek zatrucia toksycznymi produktami spalani [25]. ZRM w miejscu wezwania dokonuje ogólnych oględzin ciała, na podstawie których nie jest możliwa do ustalenia przyczyna zgonu[26]. W analizowanym materiale nie udostępniono wyników sekcji zwłok.

\section{Wnioski}

1. W powiecie łukowskim większość zdarzeń związanych z zatruciami wziewnymi występuje na terenach wiejskich.

2. Większość zdarzeń związanych z zatruciami wziewnymi powodowana jest przez tlenek węgla. 
3. The age group with the most exposure to inhalation poisonings in the operating area of SRM Łuków is 40-60 years (45\%).

4. Most inhalation poisoning events involve men (65\%).

5. Any person present during a fire may suffer from carbon monoxide poisoning.

6. The distance between the event site and the emergency medical services station is a factor determining the successful implementation of medical procedures and affecting prognosis in cases of more acute poisoning.

7. The distance between the event site and the emergency medical services station has no significant effect on prognosis in cases of light exposure where the victim managed to avoid exposure by himself/herself and the worrying symptoms occurred after several hours.

8. In the case of large employers - due to the procedures, instructions, escape routes and protection measures in place, cases of inhalation poisoning are rare in relation to the number of potentially affected people.

9. The heating season is not a significant factor increasing the number of inhalation poisonings.

\section{Abbreviatons}

$\begin{array}{ll}\text { AFA } & \text { - advanced first aid } \\ \text { ALS } & \text { - advanced life support } \\ \text { AR } & \text { - admission room } \\ \text { BLS } & \text { - basic life support } \\ \text { CH } & \text { - chest } \\ \text { CNS } & \text { - central nervous system } \\ \text { CO } & \text { - carbon monoxide } \\ \text { CO } & \text { - carbon dioxide } \\ \text { CTH } & \text { - Children's Teaching Hospital } \\ \text { ECC } & \text { - Emergency Communications Centre } \\ \text { ED } & \text { - Hospital Emergency Department } \\ \text { ED } t . & \text { - the Hospital Emergency Department in Łuków } \\ & \quad \text { at the SP ZOZ } \\ \text { EMS } & \text { - Emergency Medical Services } \\ \text { EMS team } & \text { - Emergency Medical Services Team } \\ \text { KG PSP } & \text { - the National Headquarters of the State Fire } \\ & \quad \text { Service } \\ \text { KZW } & \text { - dispatch order form } \\ \text { left } & \text { - patient left at the site } \\ \text { MAR } & \text { - Medical Air Rescue } \\ \text { MER } & \text { - medical emergency report } \\ \text { NFRS } & \text { - the National Firefighting and Rescue System } \\ \text { MEA } & \text { - medical emergency actions } \\ \text { MSWiA } & \text { - Ministry of the Interior and Administration } \\ \text { ND } & \text { - no data } \\ \text { NEMS } & \text { - National Emergency Medical Services } \\ \text { NFZ } & \text { - National Health Fund } \\ \text { NPL } & \text { - after hours medical centre } \\ \text { P1 } & \text { - basic dispatch team (rescue) } \\ \text { PPM } & \text { - parts per million } \\ \text { S1 } & \text { - specialised dispatch team (with a physician) }\end{array}$

3. Najbardziej narażona na zatrucia wziewne grupa wiekowa w rejonie działania SRM Łuków mieści się w przedziale 40-60 lat (45\%).

4. Na zatrucie wziewne bardziej narażeni są mężczyźni (65\%).

5. Każdy uczestnik pożaru jest potencjalnie narażony na zatrucie tlenkiem węgla.

6. Odległość miejsca zdarzenia od miejsca stacjonowania służb ratowniczych ma wpływ na wdrożenie procedur medycznych i dalsze rokowania dla poszkodowanego w przypadku cięższych zatruć.

7. Odległość miejsca zdarzenia od miejsca stacjonowania służb ratowniczych nie ma większego wpływu na dalsze rokowania dla poszkodowanych w przypadku lekkich ekspozycji, gdzie poszkodowany sam przerwał ekspozycje, a objawy niepokojące pojawiły się po kilku, kilkunastu godzinach.

8. W dużych zakładach pracy - ze względu na procedury postępowania, instrukcje, drogi ewakuacyjne i zabezpieczenia - liczba zatruć wziewnych jest niewielka w stosunku do liczby potencjalnie zagrożonych osób.

9. Okres grzewczy nie wpływa znacząco na wzrost zatruć wziewnych.

\section{Wykaz skrótów}

\begin{tabular}{|c|c|}
\hline ALS & $\begin{array}{l}\text { - advanced life suport (ang. zaawansowane } \\
\text { zabiegi ratunkowe- przyrządowe) }\end{array}$ \\
\hline B.D. & - brak danych \\
\hline BLS & $\begin{array}{l}\text { - basic life support (ang. podstawowe zabiegi } \\
\text { ratunkowe - bez przyrządowe) }\end{array}$ \\
\hline $\mathrm{CO}$ & - tlenek węgla \\
\hline $\mathrm{CO}_{2}$ & - dwutlenek węgla \\
\hline PR & - Centrum Powiadamiania Ratunkowego \\
\hline SK & - dziecięcy szpital kliniczny \\
\hline IF & - izba przyjęć \\
\hline KG PSP & - Komenda Główna Państwowej Straży Pożarnej \\
\hline LP & - klatka piersiowa \\
\hline MCR & - karta medycznych czynności ratunkowych \\
\hline PP & - kwalifikowana pierwsza pomoc \\
\hline KSRG & - krajowy system ratowniczo gaśniczy \\
\hline KZW & - karta zalecenia wyjazdu \\
\hline $\mathrm{R}$ & - Lotnicze Pogotowie Ratunkowe \\
\hline SWiA & $\begin{array}{l}\text { - Ministerstwo Spraw Wewnętrznych } \\
\text { i Administracji }\end{array}$ \\
\hline $\mathrm{CR}$ & - medyczne czynności ratunkowe \\
\hline$F Z$ & - Narodowy Fundusz Zdrowia \\
\hline PL & - Nocna pomoc lekarska \\
\hline ZK & - nagłe zatrzymanie krążenia \\
\hline OUN & - ośrodkowy układ nerwowy \\
\hline R.Ż. & - rok życia \\
\hline RM & - Stacja Ratownictwa Medycznego \\
\hline OR & - Szpitalny oddział ratunkowy \\
\hline $\mathrm{OR} \mathrm{t}$. & $\begin{array}{l}\text { - szpitalny oddział ratunkowy w Łukowie } \\
\text { przy SP ZOZ }\end{array}$ \\
\hline & - zespół wyjazdowy specjalistyczny (lekarski) \\
\hline & - Ratownictwo Medyczne \\
\hline
\end{tabular}


SCA

- sudden cardiac arrest

SP ZOZ - Independent Public Healthcare Unit

SRM - Emergency Medical Services Station

y.o. $\quad-$ years old
P1 - Zespół wyjazdowy podstawowy (ratowniczy)

Pozost. - pozostawiony/a w miejscu wezwania

PPM - (ang. parts per million) cząstek na milion

PRM - państwowe ratownictwo medyczne

SP ZOZ - samodzielny publiczny zakład opieki zdrowotnej

ZRM - Zespół Ratownictwa Medycznego

\section{Literature / Literatura}

[1] Dane otwarte Główny Urząd Statystyczny: www.stat.gov.pl [2.2018].

[2] Nadlewska A., Ładny J. R., Wojewódzka-Żelezniakowicz M. i in., Trucizny - definicja, rodzaje, mechanizm działania, „Postępy Nauk Medycznych" 2010, 9, 704-708.

[3] Oparczyk G, Konieczyński J. Tlenek węgla w pomieszczeniach jako efekt eksploatacji kuchni gazowych, Problemy jakości powietrza wewnętrznego w Polsce 2001, Wydawnictwa Instytutu Ogrzewnictwa i Wentylacji Politechniki Warszawskiej, Warszawa 2002, 251-258.

[4] Wojewódzka-Żelezniakowicz M., Czaban S. L., Poniatowski B., Ładny J. R., Zatrucia - epidemiologia, diagnostyka i leczenie w oddziale ratunkowym, „Postępy Nauk Medycznych” 2009, 6, 480-484.

[5] Trzos A., Zabezpieczenie medyczne imprez masowych, Kraków 2001.

[6] Mackway Jones K., Marsden J., Windle J., Triage, Ratunkowa segregacja medyczna, Elsevier Urban \& Partner, Wrocław 2012.

[7] Slavica V, Dubravko B, Milan J., Acute organophosphate poisoning: 17 years of experience of the National Poison Control Center in Serbia, "Toxicology", 2018, 409, 73-79.

[8] Buciński A., Kaliszan R., Właściwości fizykochemiczne substancji leczniczych o znaczeniu biofarmaceutycznym - rozpuszczalność, lipofilność i współczynnik dyfuzji, w: Biofarmacja, M. Sznitowska, R. Kaliszan (red.), Elsevier Urban \& Partner, Wrocław 2014.

[9] M, Kaliszan R., Biofarmacja, Elsevier Urban\&Partner, Wrocław 2013, 33-59. Cal K, Stefanowska J., Metody zwiększania przenikania substancji leczniczych przez skórę, „Farmacja Polska” 2010, 66(7), 514-520.

[10] Kapka-Skrzypczak L, Cyranka M, Kulpa P, Skrzypczak M, Wojtyła A., Dopalacze - stan aktualny i wytyczne na przyszłość, „Medycyna Ogólna i Nauki o Zdrowiu" 2011, 17(4), 206-211.

[11] Okulicz-Kozaryn K, Borucka A, Kocoń K., Przyjmowanie leków psychoaktywnych a używanie innych substancji odurzających przez młodzież, „Alkoholizm i Narkomania” 2006, 19(1), 35-52.

[12] GUS:12.2016, Powierzchnia i demografia powiatu łukowskiego [2.2018].

[13] www.polskawliczbach.pl/lukow [2.2018].
[14] Ustawa z dn. 8 września 2006 r. o Państwowym Ratownictwie Medycznym (Dz. U. 2006.191.1410) isap.sejm.go5.pl.

[15] Sohn Y.H., Carbon Monoxide poisoning, „Encyclopedia of Movement Disorders" 2010, 321-329.

[16] KG PSP - Tlenek węgla zbiera tragiczne żniwo, Aktualności www. straz.gov.pl [3.2018].

[17] Witryna internetowa MSWiA, www.mswia.gov.pl [3.2018].

[18] Klepacka M.,Sholokhova D., Bakalarski P., Kupiński K., Leszczyński P. K., The profession of a paramedic as a new specialty in the health care system - a prospective assessment of social awareness, "Critical Care Innovations" 2018, 1(2), 11-19.

[19] Klepacka M, Bakalarski P., Trust of society towards selected medical professions - doctors, nurses, paramedics, "Critical Care Innovations” 2018, 1(2), 1-10.

[20] Alarie Y., Toxicity of fire smoke. Critical reviews in toxicology 2002, 32(4), 259-289.

[21] Annane D, Chadda K, Gajdos P. i in., Hyperbaric oxygen therapy for acute domestic carbon monoxide poisoning: two randomized controlled trials, „Intensive Care Medicine” 2011, 37, 486-492.

[22] Baud F.J., Cyanide: critical issues in diagnosis and treatment, “Human \& Experimental Toxicology" 2007, 191.

[23] Centers for Disease Control and Prevention (CDC). Carbon Monoxide Exposures-United States, 2000-2009, Morb Mortal Wkly Rep (MMWR) 2011, 60(30), 1014-1017.

[24] Norkool D. M., Treatment of acute carbon monoxide poisoning with hyperbaric oxygen, „Annals of Emergency Medicine”, Volume 14, Issue 12.

[25] Karta charakterystyki nr 0032 - Tlenek węgla. Wersja 7.0., CIOP-PIB, Warszawa 2007.

[26] Krawczyk A., Bednarek M., Važanić D., Deadly dozen - „scoop and run" or "stay and play" in thoracic trauma?, "Critical Care Innovations" 2019, 2(1), 22-26.
ŁUKASZ DUDZIŃSKI, M.A. - an officer of the State Fire Service, he serves in District Headquarters of the State Fire Service in Lublin. $\mathrm{He}$ is a medical rescue instructor and a medical rescue worker in the Independent Public Health Care Institution in Łuków.

PIOTR KONRAD LESZCZYŃSKI, PH.D. - assistant professor at Nursing and Medical Rescue Department at Siedlce University of $\mathrm{Na-}$ tural Sciences and Humanities.
MGR ŁUKASZ DUDZIŃSKI - funkcjonariusz Państwowej Straży Pożarnej, pełni służbę w Komendzie Miejskiej PSP w Lublinie. Jest instruktorem ratownictwa medycznego oraz ratownikiem medycznym w Samodzielnym Publicznym Zakładzie Opieki Zdrowotnej w Łukowie.

DR PIOTR KONRAD LESZCZYŃSKI - adiunkt w Zakładzie Pielęgniarstwa i Ratownictwa Medycznego na Uniwersytecie PrzyrodniczoHumanistycznym w Siedlcach. 